\title{
Purification and Study of the Kinetic Properties of $\alpha-$ Galactosidase from Coconut Kernel
}

\author{
K. Balasubramaniam and C. D. Mathew \\ Department of Biochemistry, Faculty of Medicine, University of Colombo, Colombo, Sri Lanka.
}

(Date of receipt : 24 February 1982)

(Date of acceptance : 25 August 1982)

\begin{abstract}
The low molecular weight $\alpha$-galactosidase isoenzyme of coconut kernel, was purified until homogeneous as cetermined by polyacrylamide gel-electrophoresis. Its molecular weight (by sodium dodecyl sulphate polyacrylamide gel-electrophoresis) was 22300 daltons. The kinetic properties of the enzyme were studied using p-nitrophenyl- $\alpha$-D-galactopyranoside. The $\mathrm{Km}$ and $\mathrm{Vmax}$ values of the $\alpha$-galactosidase were $2.5 \times 10^{-4} \mathrm{M}$ and $24 \mu m$ moles/mg protein/min respectively. The enzyme was inhibited by this substrate at concentrations of $6 \times 10^{-4} \mathrm{M}$ and above. The product $\mathrm{D}$-galactose inhibited the enzyme competitively. Activation energy (as determined by the Arrhenius plot) was 10.1 Kilocalories. The $\alpha$-galactosidase is a glycoprotein with a carbohydrate content of $28 \%$; it is stable upto $45 \circ \mathrm{C}$. \%-Galactosidase activity showed a broad $\mathrm{pH}$ optimum between 2.5 and 6.0 with maximum activity at $\mathrm{pH} 5.5$.
\end{abstract}

\section{Introduction}

Galactose containing oligosaccharides and polysaccharides are carbohydrate reserves in higher plant tissues particularly in seeds. $\alpha$-Galactosidase is an exo-carbohydrase that hydrolyses the terminal $\alpha$-D-galactosidic linkage of these reserve carbohydrates.

Most plant seeds contain two $\alpha$-galactosidase isoenzymes of different molecular weights. ${ }^{8}$ Highest activity is found in mature seeds probably due to association of low molecular weight isoenzymes to form the higher molecular weight isoenzyme which has a higher specific activity. ${ }^{15}$ However two major isoenzymes have been purified from human placenta ${ }^{10}$ which are not stuucturally related and do not share a precursor and product relationship.

$\alpha$-Galactosidase is an important enzyme of the coconut seed as raffinose ${ }^{4}$ is the the predominant oligosaccharide and $61 \%$ of the polysaccharides consist of galactomannans. ${ }^{3}$ a-Galactosidase from cocount kernel has been purified by Balasubramaniam et $a l^{2}$ who separated two isoenzymes by Sephadex G-100 gel filtration in the presence of $\mathrm{KCl}$. Their apparent molecular weights were 123000 and 21000 daltons. When chromatographed in the absence of $\mathrm{KCl}$, an inactive protein peak of high molecular weight and the low molecular weight isoenzyme were obtained.

In this paper we report the purification of $\alpha$-galactosidase from coconut kernel to apparent homogeneity and also some kinetic studies carried out with the enzyme. 


\subsection{Materials}

\section{Materials and Methods}

Analytical grade BDH and Sigma chemicals were used. Mature fresh coconuts were purchased locally as and when requiled. Sephadex G-100 was purchased from Pharmacia Fine Chemicals.

Adsorbance was measured using a Pye Unicam SP 800 Spectrophotometer. Centrifugations were carried out in an IEC B-20A refrigerated centrifuge.

\subsection{Enzyme Assay'}

$\alpha$-Galactosidase was assayed by addition of suitably diluted enzyme solution $\left(0.1 \mathrm{ml}\right.$ ) in Mcllvaine buffer ${ }^{13}$ ( $\mathrm{pH}$ 5.5) containing p-nitrophenyl- $\alpha$-D-galactopyranoside $(0.5 \mathrm{mM})$ in a total volume of $1.0 \mathrm{ml}$. The mubation was carried out at $30^{\circ} \mathrm{C}$ for $15 \mathrm{~min}$ and the reaction was stopped by the addition of $0.1 \mathrm{M} \mathrm{Na}_{2} \mathrm{CO}_{3}$ solution $(5 \mathrm{ml})$. The p-nitrophenol released was measured at $405 \mathrm{~nm}$.

A unit of enzyme activity is defined as the amount that hydrolyses $1 \mu$ mole of substrate/min under the conditions specinied above.

\subsection{Protein estimation}

The protein determinations were made by the method of Lowry et al ${ }^{11}$ using crystalline bovine serum albumin as standard or by measuring the absorbance at $280 \mathrm{~nm}$.

\section{Purification of $\alpha$-galactosidase}

All operations were carried out at approximately $4^{\circ} \mathrm{C}$ urless specified otherwise.

\subsubsection{Extraction}

Coconut kernel scrapings in McIlvaine buffer ( $\mathrm{pH}$ 5.5) were homogenized using a Waring blender. The extract $(2 \mathrm{ml} / \mathrm{g})$ was passed through a cheese cloth and centrifuged at $25000 \mathrm{~g}$ for $30 \mathrm{~min}$. The superaatant was retained.

This supernatant was adjusted to $\rho \mathrm{H} 3.8$ usirg $0.5 \mathrm{M}$ citric acid. After standing for $30 \mathrm{~min}$, the acidified solution was centrifuged at $25000 \mathrm{~g}$ for $30 \mathrm{~min}$. The $\mathrm{pH}$ of the acid supernatant was readjusted to $\mathrm{pH} 5.5$ using a saturated solution of $\mathrm{Na}_{2} \mathrm{HPO}_{4}$.

\subsubsection{Ammonium sulphate fractionation}

The acid supernatant ( $\mathrm{pH}$ 5.5) was ammonium sulphate fractionated using solid ammonium sulphate. The fraction between $50 \%-75 \%$ saturation showed the highest specific activity. This precipitate was dissolved in $3 \mathrm{ml}$ of Mcllvaine buffer (pH 5.5) and dialysed against the same buffer. 


\subsubsection{Sephadex $G-100$ gel filtration}

A column $(2.4 \times 100 \mathrm{~cm})$ of Sephadex $\mathrm{G}-100$ was prepared as described by Andrews. ${ }^{1}$ The dialysed ammonium sulphate fraction $(1.5 \mathrm{mg}$ protein in $1 \mathrm{ml}$ ) was applied and eluted with. Mcllvaine buffer ( $\mathrm{pH} 5.5$ ) containing $0.0025 \%$ merthiolate. Fractions $(5 \mathrm{~m}$ !) were collected in a refrigerated fraction collector at a flow rate of $22 \mathrm{ml} / \mathrm{h}$.

\subsubsection{Concentration}

Selected fraction from Sephadex gel filtration were pooled and concentrated to about $4 \mathrm{ml}$ using an Amicon ultrafiltration cell with an UM 2 membrane under nitrogen $(2.5 \mathrm{~atm})$. The concentrated enzyme solution was centrifuged at $7000 \mathrm{~g}$ for $10 \mathrm{~min}$ and the supernatant was retained.

\subsection{Polyacrylamide gel electrophoresis}

Electrophoresis was carried out by the method of Davis ${ }^{6}$ using a Shandon apparatus . Polyacrylamide gels $(5 \%)$ were prepared and loaded with $200 \mu \mathrm{l}$ (2.5 $\mu \mathrm{g}$ protein) of the purified enzyme (diluted 2: 1 with glycerol). McIlvaine buffer pH 6.5 was used in the reservoir. Gels were stained for proteins using Coomassie blue. Their $\alpha$-galactosidase activities were tested by incubating with 4 - methyl umbelleferyl $\alpha$ - D - galactoside $(2.5 \mathrm{mM})$ at room temperature for $30 \mathrm{~min}$. The reaction was terminated with $0.5 \mathrm{M} \mathrm{NaOH}$ and the fluorescent bands observed under UV light.

\subsection{Determinationt of molecular weight}

The molecular weight of the purified enzyme was determined using SDS (Sodium Dodecyl Sulphate ) polyacrylamide gel $(10 \%)$ electrophoresis by the method of Weber et al. ${ }^{18}$ Standard proteins $(10 \mu \mathrm{g}$ each) were in a total volume of $200 \mu \mathrm{l}$. $\alpha$ - Galactosidase (3 $\mu \mathrm{g}$ ) was taken separately in $200 \mu \mathrm{l}$. To all solutions $100 \mu \mathrm{l}$ of glycerol, $5 \mu \mathrm{l}$ of mercaptoethanol and $5 \mu 1$ of Bromophenol blue were added. Electrophoresis was conducted for 3 h at $8 \mathrm{~mA}$ per tube constant current.

\section{Results}

\subsection{Purification of $\alpha$ - galactosidase}

The purification of $\alpha$ - galactosidase of coconut kernel is summarised in Table 1 . The multistep purification gave an overall yield of $11 \%$ and the $\alpha$ - galactosidase was purified 510 fold.

\subsection{Test for purity}

Polyacrylamide gel electrophoresis of purified enzyme $(2.5 \mu \mathrm{g})$ gave single and coincident band for protein and $\alpha$ - galactosidase activity. 
TABle 1. Purification of $\alpha$-galactosidase from coconut kernel

\begin{tabular}{|c|c|c|c|c|c|c|c|}
\hline Purification step & $\begin{array}{r}\text { Volu } \\
(\mathrm{m}\end{array}$ & $\begin{array}{l}\text { ume } \\
\text { hI) }\end{array}$ & $\begin{array}{l}\text { Total enzyme } \\
\text { activity } \\
\text { (units) }\end{array}$ & $\begin{array}{l}\text { Total } \\
\text { protein } \\
\text { (mg) }\end{array}$ & $\begin{array}{l}\text { Specific activity } \\
\text { (Units/mg } \\
\text { protein) }\end{array}$ & $\begin{array}{l}\text { Recovery } \\
(\%)\end{array}$ & $\begin{array}{l}\text { Purification } \\
\text { (fold) }\end{array}$ \\
\hline Extract & & 104 & 58.9 & 2080 & 0.028 & 100 & 1 \\
\hline $25000 \mathrm{~g}$ supernatant & , & 88 & 41.7 & 352 & 0.119 & 71 & 4 \\
\hline Acid supernatant & & 100 & 38.8 & 37 & 1.0 & 66 & 36 \\
\hline \multicolumn{8}{|c|}{$\begin{array}{l}\text { Ammonium sulphate } \\
\text { fraction }(50-75 \% \text { sat.) dialysed } 7\end{array}$} \\
\hline Sephadex G-100 gelf & tration 9 & 980 & 13.6 & 2.9 & 4.6 & 23 & 168 \\
\hline Concentration & & 31 & 6.6 & 0.46 & 14.3 & 11 & 510 \\
\hline
\end{tabular}

\subsection{Determination of molecular weight}

The molecular weight of the purified enzyme determined by SDS polyacrylamide gel electrophoresis appeared to be 22300 daltons (Figurc 1).

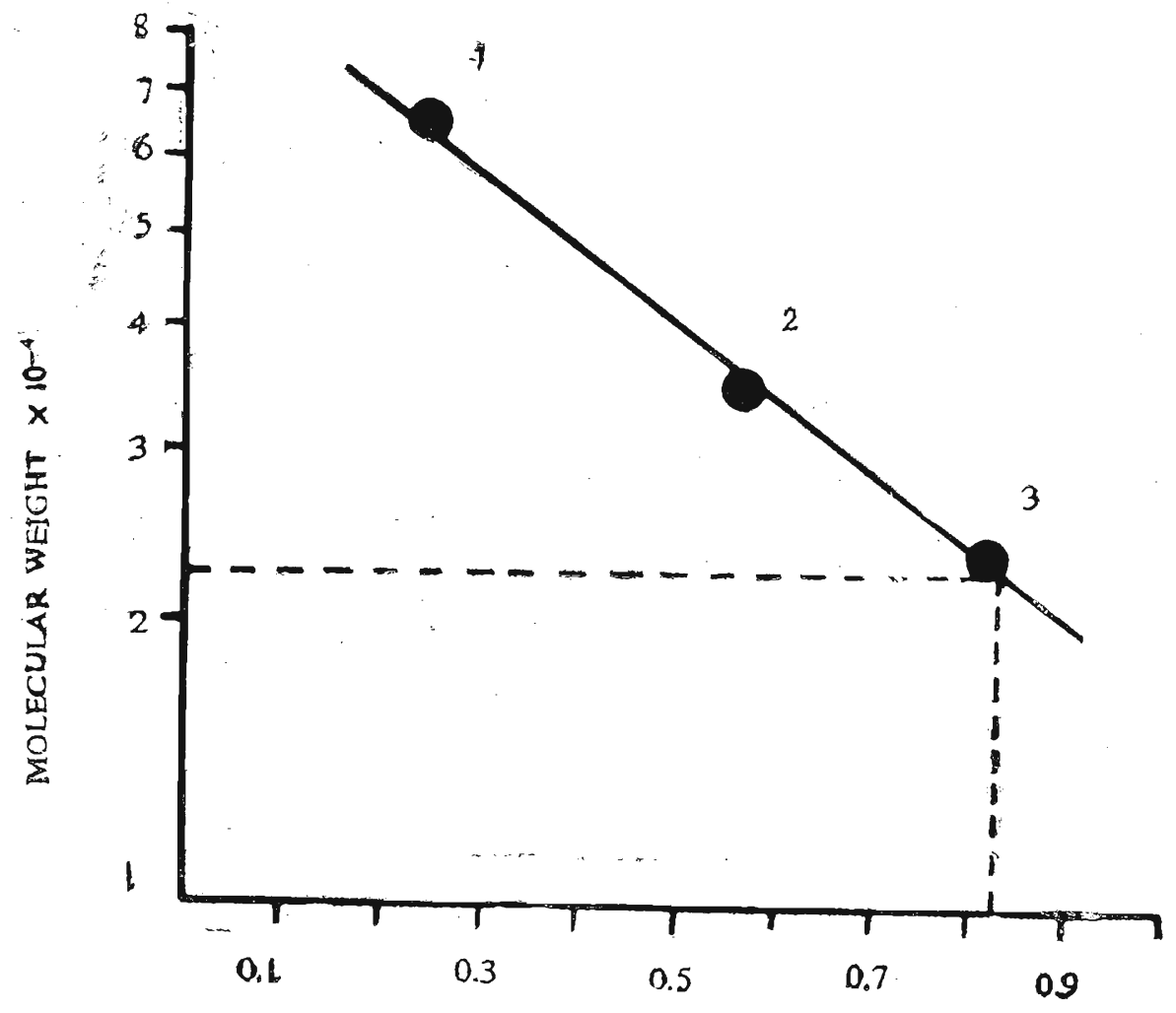

MOBILITY

Figure 1. Determination of molecular weight of $\alpha$-galactosidase by SDS polyacrylamide gel electrophoresis. 1, Bovine Serum Albumin, (M.W. 66 000); 2, Pepsin (M.W.35 000); 3, a-Chymotrypsinogen (M.W. 23650 ) Mobility (of protein $=$ (Migration of protein band/Migration of dye band) $\times$ (length of gel before staining/length of gel after staining). 


\subsection{Effect of substrate concentration and inhibitors}

$\alpha$ - Galactosidase was incubated at room temperature $\left(29^{\circ} \mathrm{C}\right)$ in Mcllvaine buffer (pH 5.5) containing p-nitrophenyl $\alpha-\mathrm{D}$ - galactopyranoside for $15 \mathrm{~min}$. The $\mathrm{Km}$ and Vmax values of $\alpha$-galactosidase for p-nitrophenyl $-\alpha-D$ - galactopyranoside determined from the linear part of the Lineweaver -Burk plot were $2.5 \times 10^{-4} \mathrm{M}$ and $24 \mu \mathrm{moles} / \mathrm{min} / \mathrm{mg}$ protein respectively. Substrate inhibition was observed at concentrations above $6 \times 10^{-4} \mathrm{M}$ (Figure 2).

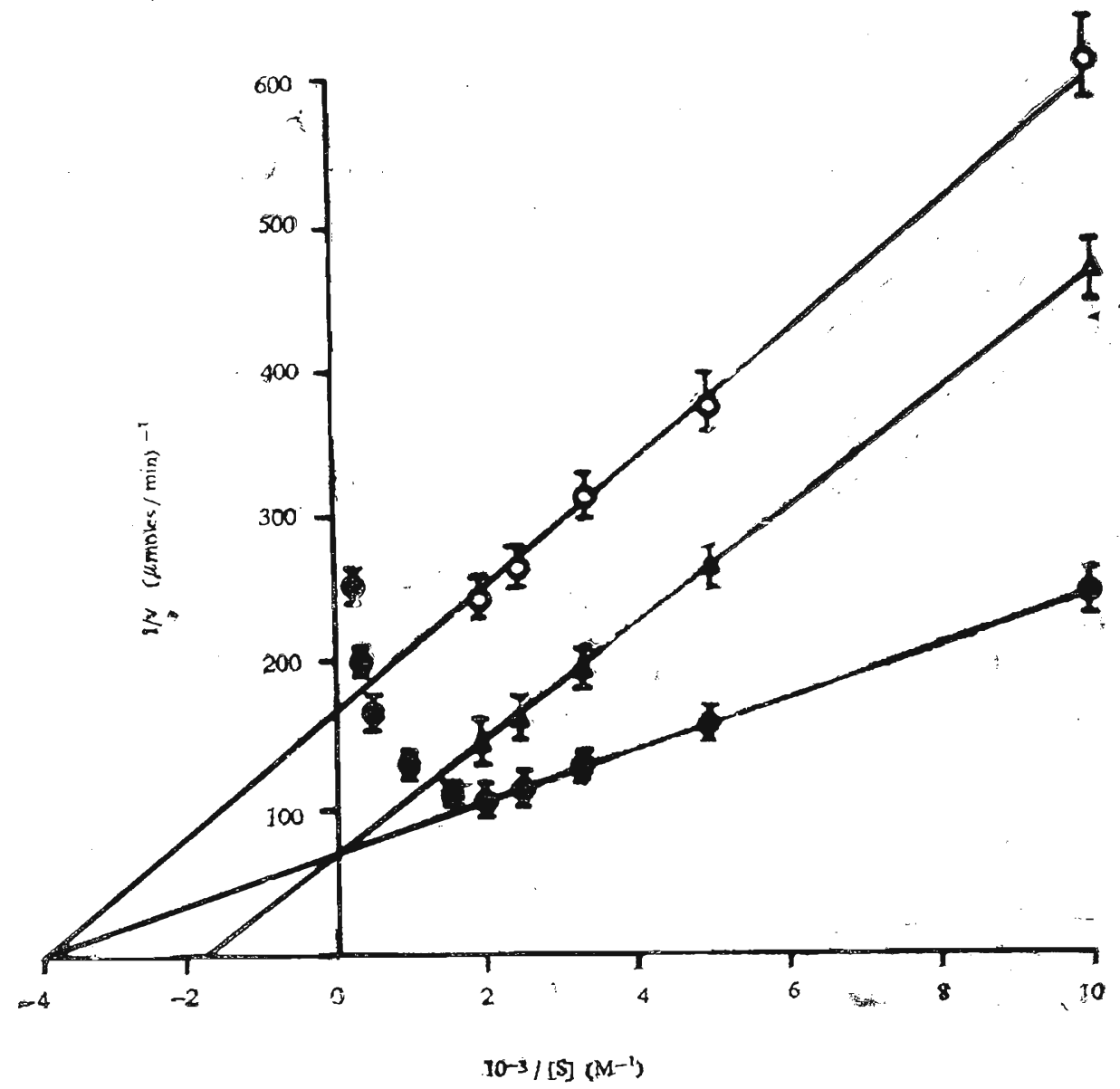

Figure 2. Lineweaver-Burk double reciprocal plot of $\alpha$-galactosidase for the substrate $p$-nitrophenyl $\alpha-D$-galactopyranoside and the inhibitors, D-galactose and mercuric ions. $\bullet$, substrate; $\Delta$, substrate $+D$-galactose $(10 \mathrm{mM}) ; \mathrm{O}$, substrate + mercuric ions $(1 \mu \mathrm{M})$. Bars indicate standard deviations obtained from four experiments. 
The effect of $\mathrm{Hg}^{2+}$ ions on $\alpha$-galactosidase activity was studied by incubating $\alpha$-galactosidase at room temperature $\left(29^{\circ} \mathrm{C}\right.$ ) in McIlvaine buffer ( $\mathrm{pH} 5.5$ ) containing mercuric chloride $(1 \mu \mathrm{M})$ for $15 \mathrm{~min}$. It was then assayed for enzyme activity. The inhititor concentration was kept constant $\left(10^{-6} \cdot \mathrm{M}\right.$ ) while the substrate concentration in the assay medium was varied from $10^{-4} \mathrm{M}$ to $5 \times 10^{-4} \mathrm{M}$. In case of $\mathrm{D}$ galactose it was added to the assay medium at a constant level $(10 \mathrm{mM})$ while the substrate concentration was varied as before. The Lineweaver - Burk plot shows that $\mathrm{Hg}^{2+}$ ions inhibit $\alpha$-galactosidase non - competitively. The inhibition by Dgalactose is competitive (Figure 2).

\subsection{Effect of $3 \mathrm{H}$ on enzyme activity.}

$\alpha$ - Galactosidase in McIlvaine buffer showed optimum activity at pH 5.5. Below pH 5.5 the activity was constant and high. While above pH 5.5 the activity declined very steeply (Figure 3).

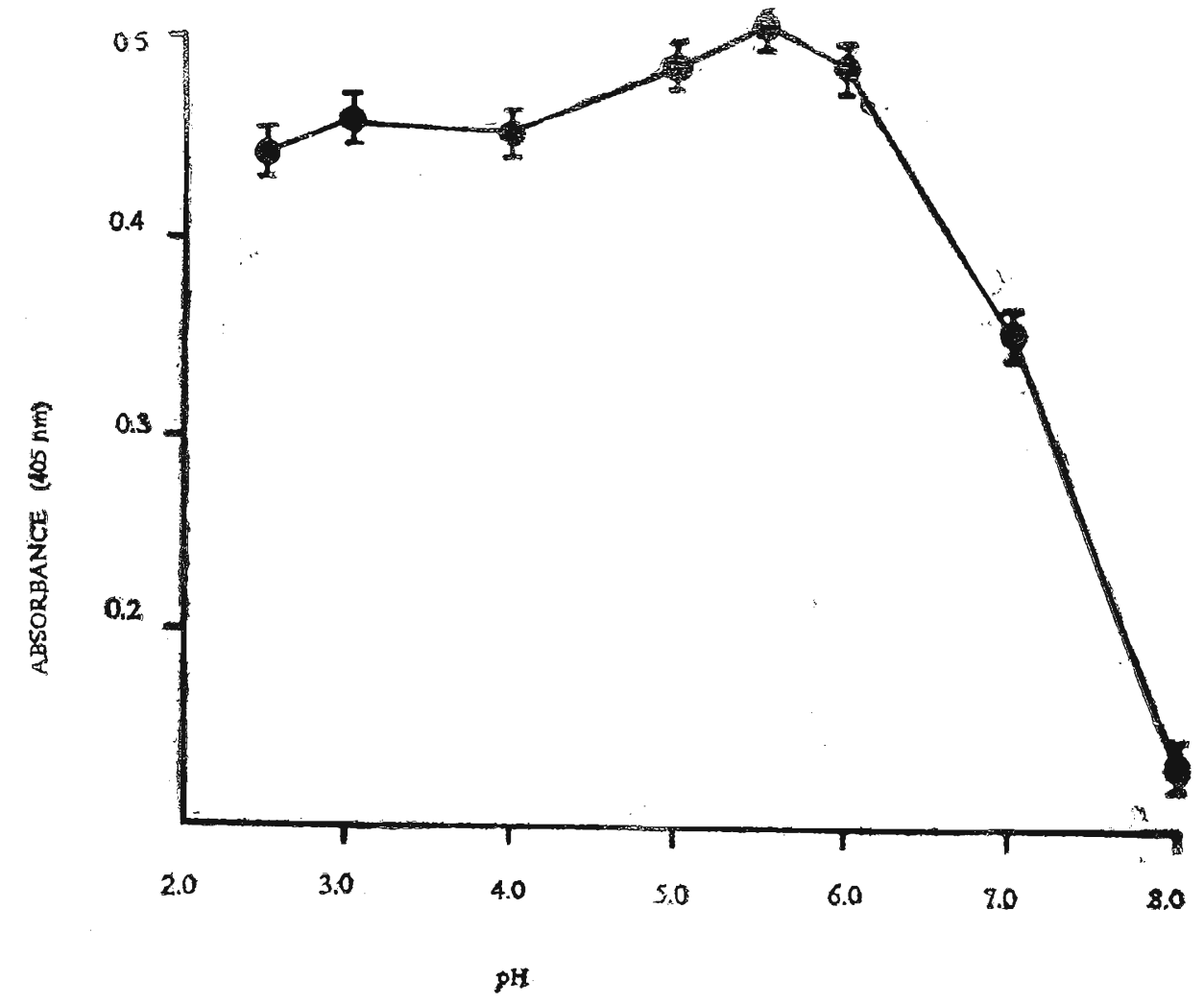

Figure 3. Effect of $\mathrm{pH}$ on $\alpha$-galactosidase activity. Bars indicate standard deviations obtained from four experiments. 


\subsection{Effect of temperature}

$\alpha$ - Galactosidase activity increased with increase in temperature from $10^{\circ} \mathrm{C}$ to $50^{\circ} \mathrm{C}$. Arrhenius plot for $\alpha$-galactosidase (Figure 4 ) gave a straight line graph showing that the energy of activation did not change with the change in temperature. The energy of activation was $10.1 \mathrm{Kcal}$.

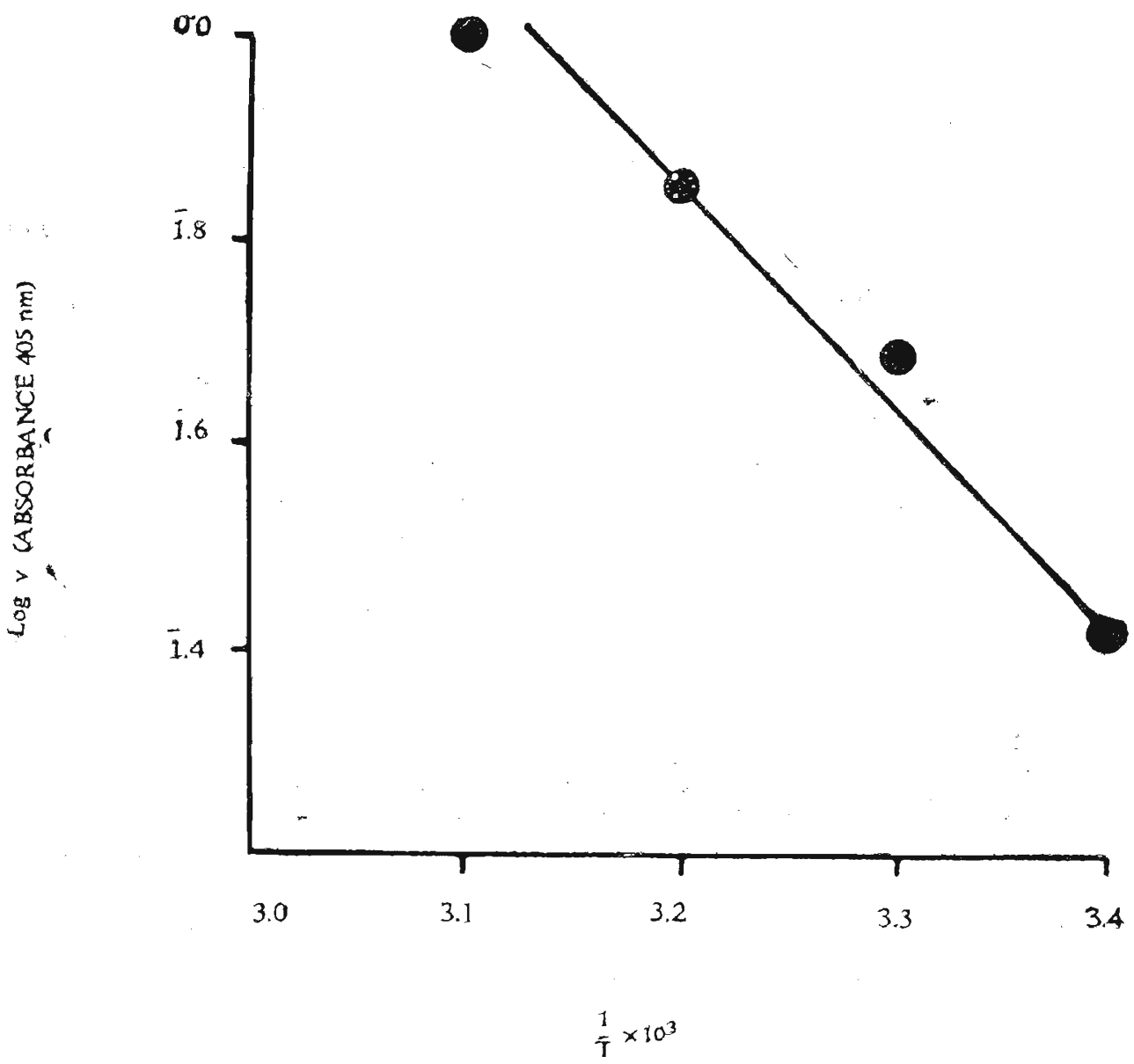

Figure 4. Arrhenius plot of $\alpha$-galactosidase for the substrate $p$-nitrophenyl- $\alpha-D$ galactopyranoside.

\subsection{Stability of $\alpha$-galactosidase at various temperatures}

The enzyme was very stable upto $45^{\circ} \mathrm{C}$ beyond which the activity declined very sharply. The enzyme lost $92 \%$ of its activity when incubated at $60^{\circ} \mathrm{C}$ for $15 \mathrm{~min}$. 


\subsection{Glycoprotein nature of $\alpha$-galactosidase}

Purified $\alpha$-galactosidase was tested for the presence of cartohydrates by the method of Dubois et $a 1^{9}$ using glucose as the standard. The carbohydrate content of purified a-galactosidase was $28 \%$.

\section{Discussion}

Homogeneous $\alpha$-galactosidase has been obtained from seeds of Vicia faba ${ }^{7}$, Vicia sativa, ${ }^{14}$ sweet almond, ${ }^{12}$ white clover ${ }^{19}$ and fungus Mortierella vinavea ${ }^{17}$ and also from the human placenta. ${ }^{10}$ The $\alpha$-galactosidase of coconut kernel obtained by our method was purified 510 fold and the yield was $11 \%$. The yield and purity are comparable to the values obtained for Vicia faba, ${ }^{7}$ Vicia sativa, ${ }^{14}$ sweet almond, ${ }^{12}$ white clover ${ }^{19}$ and Mortierella vinacea. ${ }^{17}$ The specific activity of the purified coconut $\alpha$-galactosidase is equal to the specific actirities of the enzymes obtained from V. sativa ${ }^{14}$ and sweet almond. ${ }^{12}$

Molecular weight of the purified $\alpha$-galactosidase isoenzyme of coconut was determined by SDS polyacrylamide gel electrophoresis to be 22300 daltons. The $\alpha$ galactosidase being a glycoprotein could impair the binding of SDS. ${ }^{18}$ This would result in lowering the electrophoretic mobility. The molecular weight obtained for the same enzyme by Balasubramaniam et $a^{2}$ from gel filtration was 21400 daltons. Hydration of glycoproteins and its affinity for dextran could affect the mobility of the enzyme in gel filtration. However the molecular weights of $\alpha$-galactosidase from various seeds have been determined by gel filtration and the values obtained for their low molecular weight isoenzymes varied between 25,000 daltons and 40,000 daltons. ${ }^{8}$

High concentrations of p-nitrophenyl $-\alpha-D-$ galactopyranoside inhibited the $\alpha$ - galactosidase of coconut. The inhibition by this substrate has also been observed with the $\alpha$-galactosidase of $V$. $f a b a^{7}$ and sweet almond. ${ }^{12} \mathrm{Km}$ and Vmax values obtained in this study are lowes than the values obtained using the same substrate in sweet almond, ${ }^{12} V$. sativa, ${ }^{14}$ and white clover ${ }^{19}$ but similar to that of the high molecular weight isoenzyme from $V$. faba.? Like the $\alpha$-galactosidase from coconut kernel $\alpha$-galactosidase from $M$. vinacea ${ }^{17}$ is inhibited noncompetitively by $\mathrm{Hg}^{2+}$ ions while that from $V . f a b a^{7}$ and $P$. amygdrilus ${ }^{8}$ are competitively inhibited by $\mathrm{Hg}^{2+}$ ions. D-Galactose competitively inhibits coconut $\alpha_{-}$-galactosidase. It also inhibits competitively $\alpha$-galactosidase from $V$. faba but the enzyme from $M$. vinacea ${ }^{17}$ shows a mixed type inhibition.

The $\mathrm{pH}$ optima of $\alpha$-galactosidase varied to a considerable extent when p-nitrophenyl - $\alpha$-D-galactopyranoside was used as substrate. Many $\alpha$-galactosidases showed two pH ot, tima ${ }^{7},{ }^{8}$ and the $\alpha$ - galactosidase of coconut also appears to have two peaks with maximum activity at pH 5.5. The sharp decline in activity between 
pH 6 and 8 observed with coconut $\alpha$-galactosidase indicates the presence of a catalytic group with a $\mathrm{pKa}$ of 7 at the active site which could be an imidazole group of histidine. A similar decline in activity is observed in the $\alpha$-galactosidase of sweet almond using p-nitrophenyl- $\alpha$ - D galactopyranoside as substrate and studies on the effect of $\mathrm{pH}$ on its $\mathrm{Km}$ and Vmax indicate the presence of imidazole and carboxyl groups at the active site. ${ }^{6}$ Preliminary fluorescence spectrophotometric studies indicate the involvement of a tryptophan at or near the active site of $\alpha$-galactosidase from coconut.

The energy of activation of $\alpha$ - galactosidase of coconut is lower than the reported values from other plants sources but similar to that of $M$. vinacea ${ }^{17}$ and Prunus amygdalus. ${ }^{8}$ The thermal stability that was observed in $\alpha$-galactosidase of coconut kernel is common to $\alpha$-galactosidase from $V$. faba and $M$. vinacea ${ }^{17}$ that are glycoproteins. The carbohydrate content is higher than of $\alpha$-galactosidase from $M$. vinace $a^{17}$ but is similar to the high molecular weight $\alpha$-galactosidase isoenzyme from $V . f a b a{ }^{7}$

\section{Acknowledgements}

The authors wish to thank the International Foundation of Science (Grant 441), the Natural Resources, Energy and Science Authority (Grant RG 77/28) and the University of Colombo for providing the research grants. Our thanks are also to Dr. M.C.P. Canagaratna for her advice and guidance at all times. The technical assistance of Mr. O. D. H. R. Weerasena, Mr. R. D. Sothary and Mr. G. K. J. Silva is grectly appreciated.

\section{References}

1. ANDrews, P. (1964) Biochem. J., $91: 222$

2. Balasubramaniam, K., Dey, M. \& Pridham, J. B. (1974) Biochem. Soc. Trans., 2 : 1128.

3. Balasubramaniam, K. (1976) Journul of Food Science,, $41: 1370$.

4. Carney, E. (1921) Philippines Agri., $10: 55$.

5. Davis, B.J. (1964) Ann. N. Y. Acad. Sci., $121: 404$.

6. Dey, P. M. \& Malhotra, O.P. (1969) Biochem. Biophs. Acta., 185 : 402.

7. Dey, P. M. \& PRIDHaM, J. B. (1969) Biochem. J.: $113: 49$.

8. Dey, P. M. \& Pridham, J. B. (1972) Adyances in Enzymology., 36 : 91.

9. Dubois, M., Gilles, K. A., Hamilton, J. K., Rebers, P. A. \& Smith, F. (1956) Analyt. Chem. $28: 350$.

10. Kusiak, W. M., Quirk, M. J. \& Brady, O. R. (1978) J. Biol. Chem., 253 : 194.

11. Lowry, O.H., Rosenbrough, N. J., Farr, A. L. \& Randall, R. J., (1951) J. Bio!. Chem., $193: 265$. 
12. Malhotra, O. P. \& Dey, P. M., (1967) Biochem. J., $103: 508$.

13. Mcilvaine, T. C., (1921) J. Biol. Chem., $49: 183$.

14. Petek, F., Villarroya, E. \& Courtois, J. E., (1969) Eur. J. Biochem., 8: 395.

15. Pridham, J. B. \& DeY, P. M. (1974) Nature and functions of higher plant $\alpha$-galactosidase In 'Plant Carbohydrate Biochemistry.' J. B. Pridham, ed. Academic Press, London.

16. Simpson, R. B. (1961) J. Amer. Chem. Soc., $83: 4711$.

17. Suzuki, H., Li, S. \& LI, Y. (1970) J. Biol. Chem., $245: 781$.

18. Weber, K., Pringle, J. R. \& Osborn, M., (1969) Methods in Enzymology. 26 : 3. C. H. W. Hirs \& S. N. TimashefF, ed. Academic Press, New York.

19. Williams, J., Villarroya, H. \& Petek, F. (1977) Biochem. J. $161: 509$. 